\title{
LEPROSY IN SOVIET RUSSIA
}

C. A. Sprawson.

I spent the month of September, 1938, on a medical tour in European Russia. Before going I had notified the Soviet authorities that my chief interests were Leprosy and Tuberculosis and I asked to see a leprosarium. I am also interested in medical education, but I knew I should be shown that without special request. The Commissar of Public Health replied that they did not think it worth my while to make a long journey (most of their lepers are in Asia or in the Caucasus) to see cases, but that they would show me a leprosarium near Moscow. However I knew there was a leper settlement, the Krutye Ruchi, in the Leningrad district, so when I was in Leningrad I several times repeated my request to see that institution, and was eventually told they did not wish to show it me. I found later it was I20 kilometres from Leningrad, so the distance may have been a difficulty.

In Leningrad, however, at the Institute of Medical Research and Experimental Medicine, a very fine institution, I met Professor Speransky who told me, through an interpreter, that he had been interested in leprosy and with his colleagues had for $2 \frac{1}{2}$ years done research work at the Krutye Ruchi Lazar Hospital on blocking nerves. Professor Speransky is known for life-long research on diseases of the peripheral nerves. He claimed that by the injection of novocaine in the course of the nerve in leprous cases he gave relief to trophic ulcers and to cramps of the hand and obtained general relief as well. He gave me two books by himself, one in English with only brief reference to leprosy, the other in Russian with a detailed account of his experiments. He said that he could 
not obtain acute or early cases of leprosy to work on, as there was not much of the disease in that area, and he asked me if I could get the treatment tried in some part of the British Empire where many cases occurred. I said I would bring his request to the notice of B.E.L.R.A. Here is the extract from his English book which mentions his work on Leprosy.

" In cases that had not been neglected, novocaine had a good and lasting therapeutic effect. We had a number of patients who almost regained their working capacity, chiefly owing to the restoration of sensitivity. Levelling, and in some cases, disappearance of skin nodes was also noted, as well as healing of chronic ulcers and removal of contractures. The fingers of the patient after being contracted for a number of years, regained sensitivity and mobility, even becoming capable of performing certain forms of fine work (embroidery). Similar improvement occurred in regard to the general state (subjective state, weight, appetite, sleep, etc.). It must be mentioned that in some cases it was possible by means of the novocaine blockade to do away with the sudden intense attacks experienced by leper patients, a process which is frequently the cause of death. A detailed report on this work will be given in a separate article."

Unfortunately the detailed account is in Russian, which I cannot read. I should be pleased to send this book to anyone who wishes to try the treatment suggested.

When I reached Moscow I saw the leprosarium there and was very kindly shown round by the Director, Dr. Belnov. There was really very little to see except a laboratory adequately equipped. They had thirty beds, but some time previously had decided that the neighbourhood of a large city was not a good place to keep lepers and so had sent them all to a remote settlement in the south. The Moscow place was now used only as an out-patient clinic and Dr. Belnov had only one patient, whom he showed me and whom he claimed to have cured by injections of serum from a horse that had been inoculated with some diptheroid organism. His usual treatment seemed to be by potassium iodide, but he was aware that this had been considered dangerous. He also used Alepol; but apparently did not use chaulmoogra oil or esters.

No leprolin test is applied; nor is either variety of leprolin prepared. Dr. Belnov spoke with great respect of Dr. Muir and asked me about his methods: I gave him a copy of Dr. Muir's recent book.

Dr. Belnov also gave me some interesting details of the Soviet's organisation against leprosy. He said that all lepers have to be registered and that there were only 3,000 registered 
lepers in the Soviet Union. He gave their main distribution as follows: Caucasus 700, Turkestan i,000, Astrakan 600 to 700, Far East (Vladivostock) Ioo, Yakutsh 30.

On my expressing doubt that all lepers were registered, he demurred: but I still think there must be many more than these numbers indicate.

There is no medical inspection of school children in infected areas to detect new cases.

It is not compulsory for a leper to go to a leprosarium, but Dr. Belnov said one would prefer to do so and would be unlikely to evade treatment. He said that an infective case would be compelled to reside in a leprosarium. They have special homes, outside the leprosarium, for the healthy children of patients. Children born in the settlement are separated from their parents at nine months.

In some places they have clinics for non-infective cases, like this one at Moscow. Crippled cases in whom the disease has died out are retained in a leprosarium, there being a special house for them.

Although not much has been done hitherto, it is interesting to note that recently generous financial provision has been made for the care of lepers. Dr. Belnov said that the budget for 1937 contained an allotment of I2 million roubles for leprosaria. It is impossible to give a sterling equivalent for this amount. one might put it perhaps about $£ 300$, 000. Most of this seems to be going in building. Out of this a leprosarium of 600 beds is under construction at Krasnodar in the south. Three more new leprosaria are also under construction, one near Moscow, and two in Asia.

My chief impressions about leprosy from this visit were :-

I. Leprosy is not a major problem in the Soviet Union.

2. The Soviet have hitherto not done much for it, but have been devoting their energies to more important problems, such as tuberculosis, which they are attacking with the utmost energy and with considerable success.

3. The Soviet are now tackling the problem and building more leprosaria. There remains much more to be done, however, such as inspection of school children.

One further point is of interest. The Soviet evidently regard leprosy work as a dangerous occupation, because on that account they pay their leprosy physicians much more highly, usually double, than they pay their general medical officers. 